\title{
BADANIE ZGODNOŚCI KONCEPCJI REKREACYJNO-TURYSTYCZNEGO OTWARCIA DROGI WODNEJ OŚWIĘCIM - KRAKÓW Z ZASADAMI ZRÓWNOWAŻONEGO ROZWOJU
}

\begin{abstract}
W pracy przedstawiono metodę oceny stopnia zgodności zagospodarowania akwenu wodnego z zasadami zrównoważonego rozwoju. Obszarem badawczym była droga wodna pomiędzy Oświęcimiem i Krakowem wraz z terenami przyległymi. Przedmiotem badań była koncepcja turystyczno-rekreacyjnego wykorzystania śródlądowej drogi wodnej Górnej Wisły. Koncepcja składała się z pięciu elementów tj.: ścieżek rowerowych wzdłuż Wisły wraz z siecią wypożyczalni, houseboatingu, dwóch przystani zlokalizowanych na początku i końcu trasy oraz samoobsługowych miejsc cumowniczych pomiędzy Oświęcimiem i Krakowem. Badanie stopnia zgodności koncepcji z zasadami zrównoważonego rozwoju rozpatrywane było w trzech głównych aspektach: ekonomicznym, społecznym i środowiskowym. W ramach każdego z trzech aspektów wskazano pięć najważniejszych czynników i rozpatrywano czy koncepcja jest zgodna czy sprzeczna z zasadami zrównoważonego rozwoju. W pracy przeanalizowano koncepcję turystycznorekreacyjnego zagospodarowania Górnej Wisły, zwracając uwagę na potrzebę prawidłowego gospodarowania obszarami wodnymi w ujęciu lokalnym oraz glo-
\end{abstract}

1 Autor do korespondencji / corresponding author: Emilia Miszewska-Urbańska, Politechnika Gdańska, Katedra Konstrukcji Metalowych i Zarządzania w Budownictwie, Wydział Inżynierii Lądowej i Środowiska, 80-233 Gdańsk, ul. Narutowicza 11/12, tel. + 48058347 16 37, e-mail: emiurban@pg.gda.pl

2 Adam Bolt, Politechnika Gdańska, Katedra Geotechniki, Geologii i Budownictwa Morskiego, Wydział Inżynierii Lądowej i Środowiska, 80-233 Gdańsk, ul. Narutowicza 11/12, tel. + 48 (058) 34729 03, e-mail: adam.bolt@pg.gda.pl

3 Antoni Taraszkiewicz, Politechnika Gdańska, Katedra Architektury Mieszkaniowej, Wydział Architektury, 80-233 Gdańsk, ul. Narutowicza 11/12, tel. + 4805834716 33, e-mail: antarasz@pg.gda.pl

${ }^{4}$ Radosław Wiśniewski, Uniwersytet Warmińsko-Mazurski, Katedra Gospodarki Nieruchomościami i Rozwoju Regionalnego, Wydział Geodezji, Inżynierii Przestrzennej i Budownictwa, 10-720 Olsztyn, ul. Prawocheńskiego 15 (blok 25), tel. + 48 (089) 523 49 75, fax: 0895233832 e-mail: danrad@uwm.edu.pl 
balnym, podkreślono istotność początkowej fazy planowania inwestycji na etapie studium wykonalności w zakresie przyszłego funkcjonowania i eksploatacji.

Słowa kluczowe: gospodarowanie obszarami wodnymi, wędkarstwo, przystań, stanowisko cumownicze, ścieżki rowerowe, houseboating, rozwój dróg śródlądowych

\section{Wstęp}

W wyniku postępu cywilizacyjnego obserwuje się dynamiczne zmiany zachodzące w przestrzeni geograficznej, które nie zawsze odbywają się zgodnie z zasadami zrównoważonego rozwoju. Ogólną tendencją jest powstawanie i rozwój przestrzeni miejskiej jednak oprócz miast przestrzeń geograficzną tworzy mozaika różnego typu regionów (ekosystemów lub obszarów społecznoekonomicznych), które stanowią jednostki terytorialne pozostające $\mathrm{w}$ ścisłym związku z obszarami miejskimi. Przepływ ludzi, dóbr i informacji zachodzący pomiędzy miastami i regionami jest głównym czynnikiem determinującym nieustanne zmiany antropogeniczne w przestrzeni geograficznej [1] w tym również w obszarach wodnych. Niestety często zagospodarowywanie akwenów wodnych (zwłaszcza w strefie przybrzeżnej) przez człowieka ma wymiar fragmentaryczny, nieuporządkowany, niespójny oraz lokalny. W literaturze przedmiotu nie znaleziono publikacji odnoszącej się kompleksowo do zagospodarowania akwenów wodnych wraz ze strefą przybrzeżną zgodnie z zasadami zrównoważonego rozwoju. Opisane w artykułach możliwości zagospodarowania akwenów i stref przybrzeżnych na cele turystyczne nie wskazują istotności koncepcji rozwoju zrównoważonego [2]. Dotyczy to również publikacji odnoszących się do kwestii zagospodarowania terenów nadwodnych zgodnie $\mathrm{z}$ zasadami zrównoważonego rozwoju wyłączając, jednak rozważania dotyczące akwenu [3, 4].

Zamiary wykorzystania akwenów wodnych dla potrzeb ludzi muszą opierać się na koncepcji równoważonego rozwoju w skali makro a rozpatrywane winny być w skali mikro. Dlatego autorzy poddają ocenie zgodność z zasadami zrównoważonego rozwoju autorskiego pomysłu wykorzystania drogi wodnej Górnej Wisły na cele turystyczno - rekreacyjne [5]. Obecna publikacja stanowi rozszerzoną wersję referatu, opublikowanego w materiałach konferencyjnych INFRAEKO 2016 [4].

\section{Definicje i cele zrównoważonego rozwoju}

Rozważania i analizy związane z pytaniem, czy dana inwestycja lub zamierzenie zgodne jest $\mathrm{z}$ ideą równoważonego rozwoju. Należy rozpocząć od zdefiniowania jej celu i przytoczenia stosownych definicji. W literaturze przedmiotu oraz aktach prawnych, przywoływanych jest wiele celów i definicji równoważonego rozwoju. Najczęściej wskazywanym celem jest wzrost dobrobytu społe- 
czeństwa i jednostek oraz harmonijne kształtowanie relacji pomiędzy człowiekiem a przyrodą. Inne najczęściej wymieniane cele to:

- osiągnięcie dobrobytu, sprawiedliwości (wewnątrz i międzypokoleniowej) oraz bezpieczeństwa,

- zaspokojenie fizycznych i psychicznych potrzeb człowieka poprzez prawidłowe ułożenie jego stosunku do środowiska przyrodniczego,

- zaspokojenie potrzeb podstawowych, koniecznych dla prawidłowego rozwoju fizycznego i psychicznego człowieka - osiągnięcie zrównoważonej jakości życia.

W związku z częstym wykorzystywaniem pojęcia idei zrównoważonego rozwoju w różnych dziedzinach nauki, dużą popularnością terminu oraz faktem, że jest to zagadnienie skomplikowane, można odnaleźć co najmniej kilkadziesiąt jego definicji. Najbardziej rozpowszechniona jest definicja pochodząca z Raportu Brundtlanda, wskazująca, że rozwój zrównoważony jest to rozwój, który zapewnia zaspokojenie potrzeb obecnych pokoleń, nie przekreślając możliwości zaspokojenia potrzeb pokoleń następnych.

Tym samym ideę zrównoważonego rozwoju można przedstawić za pomocą schematu, który przedstawia rys. 1. Ważną cechą idei rozwoju zrównoważonego jest jej wielopłaszczyznowość. Odnosi się ona do szeregu nauk, między innymi społecznych i przyrodniczych. Ma przy tym charakter integracyjny. Jej podstawowym celem jest zrównoważenie podstawowych elementów systemu kształtującego przyszłość społeczności ludzkiej na Ziemi, tj.: środowiska, społeczeństwa i gospodarki tak, aby rozwój jednego z elementów nie stanowił zagrożenia dla pozostałych [6]. Dotyczy to również akwenów wodnych, które ogrywają ogromną rolę w życiu człowieka, umożliwiając transport towarów, produkcję energii, rekreację i wypoczynek, zaspokajają potrzeby rolnictwa, gospodarstw domowych oraz przemysłu.

\section{Obszar badań}

Obszarem badań jest droga wodna Górnej Wisły, a w szczególności odcinek pomiędzy Oświęcimiem km 0+000 (ujście rzeki Przemszy w Oświęcimiu) a Krakowem (stopień wodny Przewóz) km 92+600. Poznanie danych ogólnych, historii kształtowania się koncepcji zagospodarowania śródlądowej drogi wodnej oraz obecnych uwarunkowań, pozwoli lepiej zapoznać się z obszarem badawczym.

\subsection{Opis ogólny}

Rzeka Wisła bierze swój początek w Beskidzie Śląskim na północnozachodnim stoku Baraniej Góry o wysokości 1240 m n.p.m. i spływa dwoma potokami Białej i Czarnej Wisełki, łączącymi się w miejscowości Wisła-Czarne w rzekę Wisłę, która do ujścia Przemszy ma charakter rzeki podgórskiej. Od 
ujścia Przemszy w Oświęcimiu rozpoczyna się Wisła żeglowna, która przepływa przez Małopolskę, centralną część kraju oraz Pomorze i wpada do Morza Bałtyckiego pod Świbnem, osiągając powierzchnię dorzecza $194424 \mathrm{~km}^{2}$ [7].

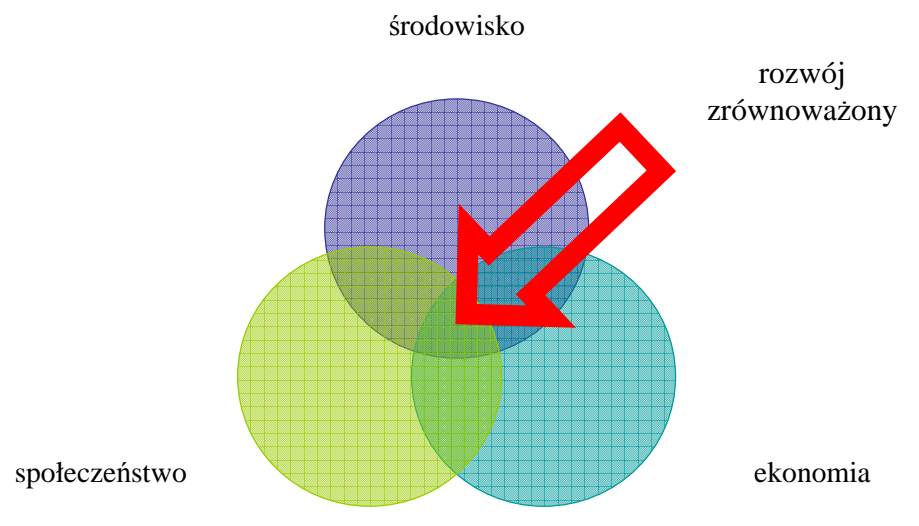

Rys. 1. Przedstawienie graficzne idei zrównoważonego rozwoju (na podstawie [6])

Fig. 1. The graphic representation of the concept of sustainable development (based on [6])

\subsection{Rys historyczny}

Żeglugę na rzece Wiśle uprawiano od dawnych czasów spławiając różne towary, m.in. drewno, zboże, sól. Jednak zmienność stanów wody i przepływów, małe głębokości i długie okresy niżówek oraz wąskie i kręte koryto były przyczyną znacznego ograniczenia sezonu żeglugowego, a z czasem całkowitej utraty przez Wisłę możliwości tranzytowych.

$\mathrm{Z}$ tego powodu na początku XX wieku pojawiła się koncepcja użeglownienia rzeki Wisły, w której zakładano że głównym towarem przewożonym drogą wodną będzie węgiel (...). Koncepcje użeglownienia Wisły ulegały wielokrotnym rewizjom, ponieważ zmieniała się m.in. liczba i lokalizacja stopni wodnych oraz ładowność przyjmowanej do przewozów barki (400, 600, 1000 ton) (...). W latach 1954-1961 wybudowano pierwsze trzy stopnie wodne kaskady związane z zaopatrzeniem rozwijającego się przemysłu w wodę:

- Przewóz,

- Dąbie,

- Łączany.

Realizację następnych elementów kaskady w roku 1963 wstrzymano z braku funduszy, lecz po 10 latach wobec pojawiających się oznak kryzysu transportowego na kolei, wznowiono działania inwestycyjne oparte na nowej wersji pro- 
jektowej. Z uwagi na potrzeby przewozowe na górnej Wiśle oraz perspektywy tranzytu na Wisłę środkową i dolną w 1974 r. opracowano nową koncepcję zabudowy o parametrach IV klasy drogi wodnej (...). Dla odcinka Wisły powyżej Krakowa zaprojektowano trzy dalsze stopnie:

- Kościuszko,

- Smolice,

- Dwory.

Budowę tych stopni rozpoczęto w latach 1976-1977. Założenia zabudowy żeglugowej górnej Wisły uległy po 10 latach dezaktualizacji wskutek zaistniałego kryzysu gospodarczego oraz zasadniczej rewizji założeń wykorzystania żeglugowego Wisły na całej długości, od Śląska do Gdańska. Nastąpiła kolejna korekta programu zabudowy górnej Wisły. Podjęto decyzję o dokończeniu budowy trzech stopni (Dwory, Smolice, Kościuszko) oraz stworzeniu warunków sprzyjających wprowadzeniu floty dostosowanej do zrealizowanych wcześniej obiektów (Przewóz, Dąbie, Łączany).

Użeglownienie Wisły na odcinku Oświęcim-Kraków miało służyć przewozom towarowym węgla do dużych elektrowni, m.in. Skawina, Kraków - Łęg, a także do kombinatu metalurgicznego - Huty im. T.Sendzimira (obecnie ArcelorMittal Poland) z kopalń węgla kamiennego [8].

\subsection{Obecne uwarunkowania}

Obecnie Wisłę żeglowną można podzielić na następujące odcinki [9]:

- Wisła górna - od ujścia Przemszy (0,0 km) do ujścia Sanu $(279,7$ km),

- Wisła środkowa - od ujścia Sanu do ujścia Świdra (490,0 km),

- Wisła Warszawska - od ujścia Świdra do ujścia Narwi $(550,5 \mathrm{~km})$,

- Wisła dolna - od ujścia Narwi do ujścia Morza Bałtyckiego (941,3 km).

Wisła górna znajduje się w administracji Regionalnego Zarządu Gospodarki Wodnej w Krakowie od km 0+000 (ujście rzeki Przemszy w Oświęcimiu) do km 295+200 (ujście rzeki Sanny w Annopolu). W zależności od warunków nawigacyjnych drogę wodną zaklasyfikowano do klas przedstawionych poniżej: (zgodnie z Rozporządzeniem Rady Ministrów z dnia 7 maja 2002 r. w sprawie klasyfikacji śródlądowych dróg wodnych - Dz. U. 2002 r. nr 77, poz. 695):

- od km 0+000 (ujście rzeki Przemszy) do km 37+500 (wlot do Kanału Łączańskiego) - klasa drogi wodnej IV (o obniżonych parametrach),

- Kanał Łączański (o długości 17,2 km) - klasa kanału II,

- od km 57+800 (wylot z Kanału Łączańskiego) do km 92+600 (stopień wodny Przewóz) - klasa drogi wodnej III,

- od km 92+600 (stopień wodny Przewóz) do km 295+200 (ujście rzeki Sany) - klasa Ib [8].

Informacje te schematycznie przedstawiono na rys. 2 . 


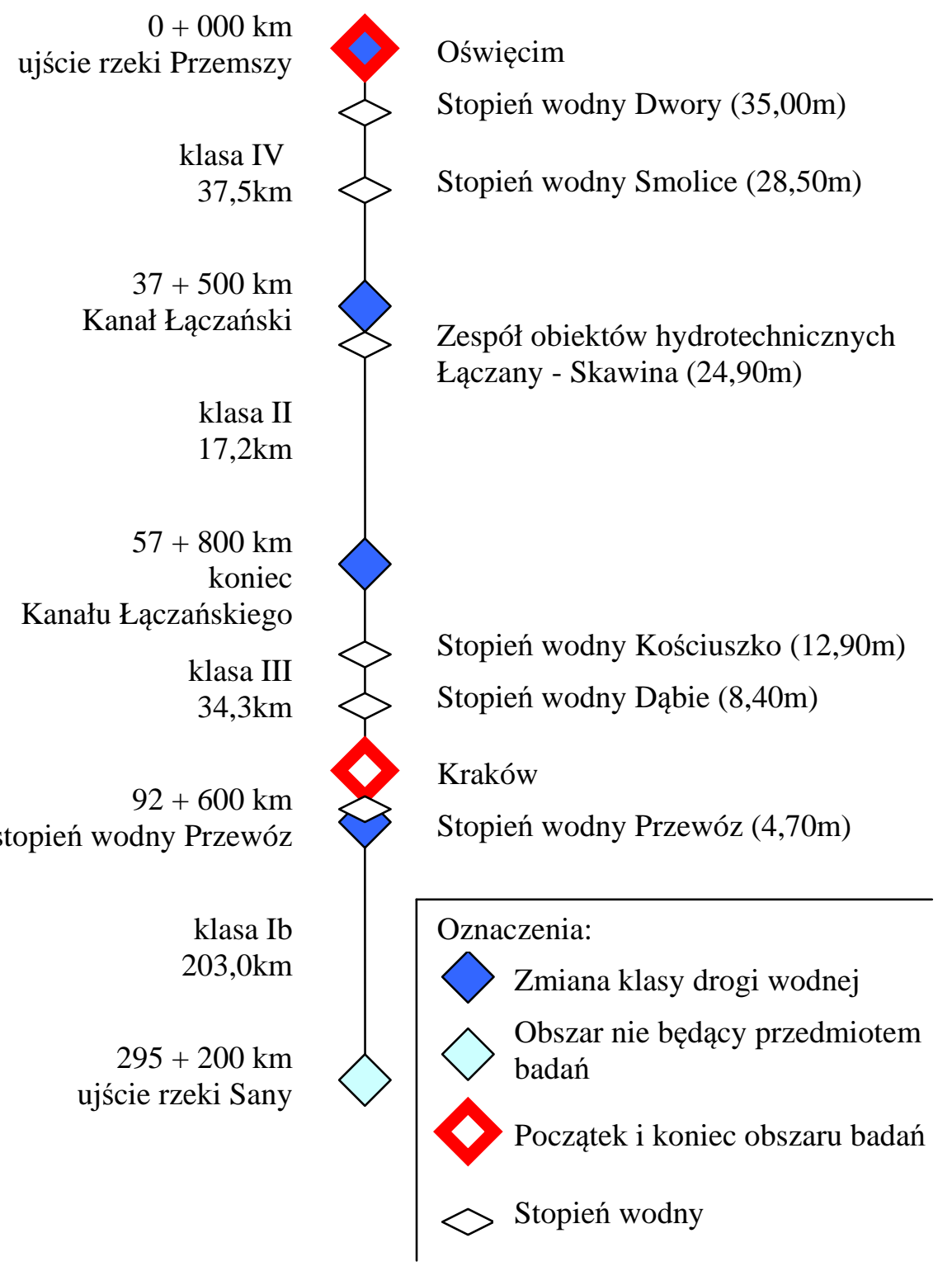

Rys. 2. Schematyczne przedstawienie drogi wodnej Górnej Wisły będącej obszarem badań

Fig. 2. Schematic representation of the Upper Vistula waterway which area of research

Spadek zainteresowania transportem wodnym w okresie ostatnich lat oraz zmiana priorytetów działań w gospodarce wodnej na rzecz ochrony naturalnych walorów rzeki sprawiły, że zrealizowany odcinek Kaskady Górnej Wisły pozostaje obecnie lokalną drogą wodną, na której przewozy towarowe ograniczają się 
wyłącznie do transportu piasku, żwiru i kamienia przeznaczonego dla celów budowlanych. Równocześnie znacznie wzrosło zainteresowanie żeglugą turystyczną, głównie w rejonie Krakowa [8].

\section{Przedmiot badań}

Przedmiotem badań jest powstały w oparciu o wyżej wymienione uwarunkowania pomysł turystyczno-rekreacyjnego wykorzystania drogi wodnej Górnej Wisły na odcinku Oświęcim-Kraków, który szczegółowo przedstawiono w pracy pt. „Rekreacyjno turystyczne otwarcie drogi wodnej Oświęcim - Kraków”. Podstawowe założenia przedstawionej propozycji oraz formy jej realizacji, obejmują:

- zagospodarowanie tras rowerowych wzdłuż kanału poprzez wykonanie ścieżek rowerowych z możliwością wypożyczenia i zwrócenia roweru na trasie (w ostępach ok. $10 \mathrm{~km}$ ) - nawierzchnia ścieżek utwardzona w taki sposób, aby można było uprawiać narciarstwo biegowe i rolkarstwo,

- zorganizowanie houseboatingu (w systemie rozwiniętym w Wielkiej Brytanii),

- budowę i organizację systemu przystani wyposażonych w infrastrukturę tak aby można było wypożyczyć łódź do houseboatingu lub łódź motorową do turystyki wodnej i zostawić ją w określonych punktach na trasie,

- budowę stanowisk cumowniczych dla domów pływających skonstruowanych na pontonach, jako domów letniskowych, które w ramach potrzeb można by przestawiać w miejsca zarezerwowane przez turystów,

- przygotowanie w określonych miejscach odpowiednich stanowisk dla wędkarzy (np. zadaszone pomosty) [8].

\section{Metoda badań}

Do oceny stopnia zgodności zagospodarowania akwenów wodnych z zasadami równoważonego rozwoju wybrano koncepcję otwarcia rekreacyjnoturystycznego drogi wodnej Oświęcim - Kraków. Ocenę stopnia zgodności przeprowadzono metodą opisową. Analizę przeprowadzono w trzech głównych płaszczyznach zrównoważonego rozwoju. Badanie rozpoczęto od określenia zasięgu obszaru badawczego, zebrania podstawowych danych oraz sprawdzenia wcześniejszych uwarunkowań. Następnie określono sposób jego zagospodarowania i tą koncepcję poddano analizie badania stopnia zgodności pod względem rozwoju zrównoważonego. Analizę trzech głównych aspektów: ekonomicznego, społecznego i środowiskowego sprawdzono za pomocą odpowiedzi na trzy pytania:

1. Czy rozwiązania z proponowanej koncepcji będą opłacalne ekonomicznie?

2. Czy rozwiązania przyjęte w koncepcji nie wpłyną negatywnie na stan środowiska naturalnego? 
3. Czy koncepcja jest akceptowana społecznie i będzie służyła większej grupie mieszkańców i turystów?

(Zastosowanie metody trzech pytań, zostało szerzej przedstawione w publikacji Pani Agaty Ćwik pt. „Zastosowanie metody „trzech pytań” w planowaniu rozwoju zrównoważonego korytarz Wisłoka w Rzeszowie" [4]).

Dla każdego z aspektów, wyszczególniono pięć najistotniejszych czynników odpowiadających za rozwój zrównoważony i na tej podstawie określono czy dana koncepcja/projekt spełnia czy nie spełnia powyższe wymogi, czy może jest dla nich obojętna. Wyniki zostały zestawione w tab. 1-3.

Tabela 1. Aspekt ekonomiczny zrównoważonego rozwoju

Table 1. The economic aspect of sustainability development

\begin{tabular}{|c|c|c|}
\hline \multicolumn{3}{|c|}{ Aspekt ekonomiczny } \\
\hline \multirow{2}{*}{$\begin{array}{c}\text { Czynniki } \\
\text { zrównoważonego } \\
\text { rozwoju }\end{array}$} & \multicolumn{2}{|c|}{$\begin{array}{l}\text { Czy rozwiązania z koncepcji turystyczno-rekreacyjnego otwarcia } \\
\text { drogi wodnej Oświęcim-Kraków będą opłacalne ekonomicznie? }\end{array}$} \\
\hline & Część opisowa & Ocena \\
\hline $\begin{array}{c}\text { Rozwój } \\
\text { krajowych } \\
\text { dróg wodnych }\end{array}$ & $\begin{array}{l}\text { Ministerstwo Gospodarki i Żeglugi Śródlądowej planuje, że } \\
\text { do } 2030 \text { r. polskie odcinki dróg wodnych: E-30 (Dunaj, } \\
\text { Bratysława - Morze Bałtyckie, Szczecin), E-40 (Morze } \\
\text { Bałtyckie, Gdańsk - Morze Czarne, Odessa) i E-70 (Atlan- } \\
\text { tyk, Antwerpia - Morze Bałtyckie, Kłajpeda) zostaną zmo- } \\
\text { dernizowane, uzyskując co najmniej IV międzynarodową } \\
\text { klasę żeglowności [11]. Odcinek drogi wodnej Górnej } \\
\text { Wisły ma zostać połączony z drogą E-30 Kanałem Śląskim. } \\
\text { Koncepcja rozwoju turystyki na rozpatrywanym obszarze } \\
\text { nie zagraża planom rozwoju dróg wodnych w Polsce przed- } \\
\text { stawionych przez Ministerstwo Gospodarki i Żeglugi Sród- } \\
\text { lądowej. W wielu krajach Europy na jednym akwenie roz- } \\
\text { wija się transport śródlądowy oraz turystyka. Współistnie- } \\
\text { nie na jednym akwenie poszczególnych jednostek regulują } \\
\text { przepisy dotyczące żeglugi. }\end{array}$ & Obojętna \\
\hline $\begin{array}{l}\text { Rozwój lokalnej } \\
\text { drogi wodnej } \\
\text { Oświęcim - } \\
\text { Kraków }\end{array}$ & $\begin{array}{l}\text { Lokalnie droga wodna Oświęcim - Kraków wykorzystywa- } \\
\text { na jest w niewielkim stopniu w celach transportowych. } \\
\text { Zwiększony ruch na drodze wodnej nie powinien spowo- } \\
\text { dować utrudnień dla lokalnych przedsiębiorstw. Dzięki } \\
\text { większemu ruchowi turystycznemu istniejąca infrastruktura } \\
\text { hydrotechniczna zacznie być wykorzystywana adekwatnie } \\
\text { do założeń dla jakich została zaprojektowana. Poprzez } \\
\text { zwiększoną liczbę śluzowań, zwiększą się wpływy z tytułu } \\
\text { opłat. }\end{array}$ & Spełnia \\
\hline
\end{tabular}


Tabela 1. Aspekt ekonomiczny zrównoważonego rozwoju (cd.)

Table 1 . The economic aspect of sustainability development (cd.)

\begin{tabular}{|c|c|c|}
\hline $\begin{array}{c}\text { Koszty } \\
\text { inwestycji }\end{array}$ & $\begin{array}{l}\text { Koszty realizacji inwestycji, zwłaszcza jej czterech głów- } \\
\text { nych elementów (houseboating, ścieżki rowerowe, przysta- } \\
\text { nie i stanowiska cumownicze) będzie znaczący. Oprócz } \\
\text { kosztów przygotowania i realizacji budowy, należy również } \\
\text { uwzględnić koszty jej utrzymania. Dlatego przed rozpoczę- } \\
\text { ciem inwestycji trzeba położyć szczególny nacisk na zapla- } \\
\text { nowanie struktury zarządzania, ilości partnerów i podziału } \\
\text { ich kompetencji oraz należy określić źródła finansowania, } \\
\text { obliczyć koszty utrzymania oraz wysokość wpływów } \\
\text { z inwestycji. }\end{array}$ & $\begin{array}{c}\mathrm{Nie} \\
\text { spełnia }\end{array}$ \\
\hline $\begin{array}{l}\text { Odbiorcy } \\
\text { projektu }\end{array}$ & $\begin{array}{l}\text { Zainteresowanie projektem w ocenie autorów będzie znacz- } \\
\text { ne przy odpowiednim funkcjonowaniu i promocji. Opinia ta } \\
\text { poparta jest danymi jakie zebrano w dokumencie pt. „Bada- } \\
\text { nie ruchu turystycznego w Województwie Małopolskim } \\
\text { w roku 2015” wykonanym dla Urzędu Marszałkowskiego } \\
\text { Województwa Małopolskiego. Dane wskazują duży poten- } \\
\text { cjał regionu, stały wzrost zainteresowania turystyką na } \\
\text { danym obszarze, znaczną liczbę turystów zagranicznych. Te } \\
\text { same opracowanie wskazuje że turyści i mieszkańcy naj- } \\
\text { bardziej zainteresowani są turystyką rowerową oraz wodną, } \\
\text { szukają nowych atrakcji oraz planują wypoczynek } \\
\text { z uwzględnieniem zmiany miejsca noclegu. Powyższe } \\
\text { potrzeby nie są w pełni zaspokojone co pozwala przypusz- } \\
\text { czać że koncepcja przytoczona w pracy będzie ciekawym } \\
\text { jej uzupełnieniem. Pomysłem houseboatingu, najbardziej } \\
\text { zainteresowani mogą być turyści zagraniczni, którzy już } \\
\text { korzystają z tej formy wypoczynku. To właśnie liczni gości } \\
\text { z Wielkiej Brytanii mogą przekonać Polaków do tej formy } \\
\text { wypoczynku. }\end{array}$ & Spełnia \\
\hline $\begin{array}{c}\text { Korzyści } \\
\text { dla regionu }\end{array}$ & $\begin{array}{l}\text { Ruch turystyczny na drodze wodnej Oświęcim-Kraków } \\
\text { przy odpowiednim rozlokowaniu miejsc cumowniczych } \\
\text { może wpłynąć korzystnie na wzrost zainteresowania po- } \\
\text { szczególnymi miejscowościami na trasie. Przekłada się to } \\
\text { nie tylko na potencjalne przychody dla restauracji, sklepów } \\
\text { i miejsc świadczących usługi noclegowe. Powoduje, rów- } \\
\text { nież powstanie miejsc pracy oraz miejsc do wypoczynku. } \\
\text { Dodatkowo zagospodarowanie akwenu oraz terenów przy- } \\
\text { ległych wpływa na wzrost cen gruntów w okolicach inwe- } \\
\text { stycji i pobudza do rozwoju lokalne społeczności. }\end{array}$ & Spełnia \\
\hline
\end{tabular}


Tabela 2. Aspekt społeczny zrównoważonego rozwoju

Table 2. The social aspect of sustainable development

\begin{tabular}{|c|c|c|}
\hline \multicolumn{3}{|c|}{ Aspekt społeczny } \\
\hline \multirow{2}{*}{$\begin{array}{c}\text { Czynnik } \\
\text { zrównoważonego } \\
\text { rozwoju }\end{array}$} & \multicolumn{2}{|c|}{$\begin{array}{c}\text { Czy koncepcja jest akceptowana społecznie i będzie służyła większej } \\
\text { grupie mieszkańców? }\end{array}$} \\
\hline & Część opisowa & Ocena \\
\hline $\begin{array}{c}\text { Zagospodarowanie } \\
\text { terenów } \\
\text { przyległych } \\
\text { do akwenu }\end{array}$ & $\begin{array}{l}\text { Zagospodarowanie trasy rowerowej wzdłuż drogi wodnej } \\
\text { Górnej Wisły nie jest nowym pomysłem. Wiślana Trasa } \\
\text { Rowerowa miała biec wzdłuż Wisły, łącząc Beskidy } \\
\text { z Bałtykiem. Trasy rowerowe poprowadzono drogami cał- } \\
\text { kowicie wyłączonymi z ruchu, koronami wałów z dwóch } \\
\text { stron Wisły. Na odcinku od Tyńca do Niepołomic istnieje } \\
40 \text { km malowniczej drogi rowerowej, która jest odcinkiem } \\
\text { europejskiej trasy rowerowej EuroVelo. Koncepcja zakłada } \\
\text { wytyczenie i zaprojektowanie drogi rowerowej od Oświę- } \\
\text { cimia do Tyńca wzdłuż Wisły w taki sposób aby na- } \\
\text { wierzchnia mogła służyć latem rowerzystom i rolkarzom } \\
\text { a zimą miłośnikom narciarstwa biegowego. W celu podnie- } \\
\text { sienia jej atrakcyjności powinna biec jak najbliżej wody. } \\
\text { Wzdłuż trasy poza zaprojektowaniem ścieżek rowerowych } \\
\text { przewiduje się powstanie kilku punktów z możliwością } \\
\text { wypożyczenia roweru, w tym roweru dziecięcego. System } \\
\text { wypożyczalni powinien funkcjonować w taki sposób, że } \\
\text { pobierający rower turysta może go zwrócić w tym samym } \\
\text { lub innym oznaczonym punkcie na trasie. System miejskich } \\
\text { rowerów został skutecznie wdrożony w Krakowie i na stałe } \\
\text { wpisał się w wizerunek miasta [10]. }\end{array}$ & Spełnia \\
\hline $\begin{array}{l}\text { Rekreacja } \\
\text { i turystyka } \\
\text { wodna }\end{array}$ & $\begin{array}{l}\text { Houseboating, to bardzo popularny sposób na spędzanie } \\
\text { wolnego czasu w Wielkiej Brytanii, Niemczech, Holandii } \\
\text { czy Francji. Opiera się on na wykorzystaniu przystosowanej } \\
\text { do zamieszkania łodzi jako domu, który w dowolnym mo- } \\
\text { mencie można przecumować w nowe miejsce. Przewaga } \\
\text { nad żaglówkami jest taka że nie trzeba posiadać specjalnych } \\
\text { uprawnień do sterowania łodzią i sprawdza się w żegludze } \\
\text { zwłaszcza wąskimi kanałami. Sprawa uprawnień będzie } \\
\text { w jednym z poważniejszych utrudnień w rozwoju tej branży } \\
\text { turystycznej w Polsce. Z uwagi na warunki nawigacyjne } \\
\text { jakie występują na drodze wodnej Oświęcim-Kraków, domy } \\
\text { pływające są jednostkami mogącymi swobodnie przemiesz- } \\
\text { czać się na tej trasie, będąc atrakcją dla mieszkańców oraz } \\
\text { turystów krajowych i zagranicznych. Wynajem domu pły- } \\
\text { wającego z możliwością jego przemieszczania może być } \\
\text { alternatywą dla konwencjonalnych sposobów spędzania } \\
\text { wolnego czasu i zachętą dla turystów zagranicznych do } \\
\text { skorzystania z formy wypoczynku jaki już znają [10]. }\end{array}$ & Spełnia \\
\hline
\end{tabular}


Tabela 2. Aspekt społeczny zrównoważonego rozwoju (cd.)

Table 2. The social aspect of sustainable development (cd.)

\begin{tabular}{|c|c|c|}
\hline Zatrudnienie & $\begin{array}{l}\text { Powstanie projektu spowoduje powstanie miejsc pracy dla } \\
\text { lokalnych mieszkańców. Do obsługi infrastruktury potrzebny } \\
\text { będzie zespół/zespoły w zależności od przyjętej formy zarzą- } \\
\text { dzania. Począwszy od koordynatorów poszczególnych punk- } \\
\text { tów i działan, po obsługę techniczną, obsługę świadczącą } \\
\text { usługi sprzątania, itp. Wzmożony ruch turystyczny zwłaszcza } \\
\text { sezonie letnim powoduje zwiększenia zatrudnienia. }\end{array}$ & Spełnia \\
\hline $\begin{array}{l}\text { Zaspokojenie } \\
\text { obecnych } \\
\text { potrzeb } \\
\text { rekreacyjnych } \\
\text { mieszkańców }\end{array}$ & $\begin{array}{l}\text { Zaspokojenie potrzeby mieszkańców na przestrzeń do odpo- } \\
\text { czynku w bliskiej odległości od miejsca zamieszkania i różnej } \\
\text { formy aktywności zawarto w przedstawionej koncepcji. } \\
\text { Projekt adresowany jest do wszystkich grup społecznych, } \\
\text { ludzi w każdym wieku, zwłaszcza tych mniej zamożnych, } \\
\text { których nie stać na wakacje poza miejscem zamieszkania. } \\
\text { Poprzez zwrócenie uwagi na turystykę rowerową oraz wodną } \\
\text { otwiera się więcej możliwości zrzeszenia ludzi w grupach } \\
\text { zainteresowań od najmłodszych do ludzi w podeszłym wieku. } \\
\text { Powstanie miejsc dla wędkarzy zwiększa bezpieczeństwo } \\
\text { wędkujących i osób korzystających z akwenu wodnego. } \\
\text { Powoduje że np. Okręgowy Związek Wędkarski zaczyna } \\
\text { identyfikować się z danym miejscem dbając o infrastrukturę, } \\
\text { wspomagając działania sprzyjające zarybianiu czy utrzyma- } \\
\text { niu czystości wody na danym obszarze. }\end{array}$ & Spełnia \\
\hline $\begin{array}{c}\text { Lokalne } \\
\text { inicjatywy }\end{array}$ & $\begin{array}{l}\text { Nowe inicjatywy i wzmożony ruch turystyczny, wpływa } \\
\text { korzystnie na integrację mieszkańców w lokalnych społecz- } \\
\text { nościach. Chęć pokazania walorów danej miejscowości, } \\
\text { powstanie miejsc spotkań czy możliwość realizowania } \\
\text { wspólnych pasji powoduje powstanie nowych klubów } \\
\text { i stowarzyszeń sportowych, muzycznych czy kulturalnych. }\end{array}$ & Spełnia \\
\hline
\end{tabular}

\section{Podsumowanie}

Badanie stopnia zgodności zagospodarowania akwenów wodnych z zasadami zrównoważonego rozwoju miało na celu zwrócenie uwagi na problem prawidłowego gospodarowania obszarami wodnymi w ujęciu lokalnym i globalnym, podkreślenie istotności początkowej fazy planowania inwestycji na etapie studium wykonalności zwłaszcza w zakresie funkcjonowania i eksploatacji.

W wyniku przeprowadzonej analizy wykazano że koncepcja zagospodarowania akwenów wodnych na cele turystyczno-rekreacyjne przedstawione w niniejszej publikacji jest zgodna $\mathrm{z}$ wymogami każdego $\mathrm{z}$ rozpatrywanych aspektów. Największą zgodność wykazuje aspekt społeczny, ponieważ aż pięć z rozpatrywanych czynników spełnia oczekiwania koncepcji zrównoważonego rozwoju. Aspekt ekonomiczny natomiast obarczony jest największym ryzykiem, ponieważ koszt inwestycji jest czynnikiem niespełniającym kryteriów. Dodat- 
kowo inwestycja jest obojętna dla planów rozwoju krajowych dróg wodnych. Mimo tych niezgodności koncepcja przedstawiona w niniejszej pracy $\mathrm{w}$ dużej mierze jest zgodna z zasadami zrównoważonego rozwoju. Istotne jest aby prawidłowo zapisać i następnie konsekwentnie realizować zapisy studium wykonalności inwestycji zwłaszcza w fazie funkcjonowania i eksploatacji.

Tabela 3. Aspekt środowiskowy zrównoważonego rozwoju

Table 3. The environmental aspect of sustainable development

\begin{tabular}{|c|c|c|}
\hline \multicolumn{3}{|c|}{ Aspekt środowiskowy } \\
\hline \multirow{2}{*}{$\begin{array}{c}\text { Czynniki } \\
\text { zrównoważonego } \\
\text { rozwoju }\end{array}$} & \multicolumn{2}{|c|}{$\begin{array}{c}\text { Czy rozwiązania przyjęte w koncepcji nie wpłyną negatywnie na stan } \\
\text { środowiska naturalnego? }\end{array}$} \\
\hline & Część opisowa & Ocena \\
\hline $\begin{array}{l}\text { Nowoczesne } \\
\text { rozwiązania } \\
\text { techniczne } \\
\text { w turystyce } \\
\text { wodnej }\end{array}$ & $\begin{array}{l}\text { Transport śródlądowy to jeden z najbezpieczniejszych } \\
\text { i najbardziej proekologicznych rodzajów przemieszczania } \\
\text { ludzi i towaru. Pojawienie się jednostek popularnie nazywa- } \\
\text { nymi domami na wodzie nie powinno powodować zagroże- } \\
\text { nia dla środowiska. Nowoczesne houseboaty o konstrukcji } \\
\text { pływającej powstałej na pływaku mają wiele nowoczesnych } \\
\text { i proekologicznych rozwiązań. Począwszy od zbiorników } \\
\text { zlokalizowanych w pływakach na wodę czystą oraz na feka- } \\
\text { lia, baterie słoneczne jako źródło energii elektrycznej, moż- } \\
\text { liwość zbierania i wykorzystania wody deszczowej. Prędkość } \\
\text { przemieszczania się jednostek nie jest duża. W celu zapew- } \\
\text { nienia wysokich standardów ochrony środowiska proponuje } \\
\text { się aby to inwestor zakupił domy na wodzie i dopilnował aby } \\
\text { każdy z nich był wyposażony w nowoczesne rozwiązania } \\
\text { proekologiczne. }\end{array}$ & Spełnia \\
\hline $\begin{array}{l}\text { Nowoczesne } \\
\text { rozwiązania } \\
\text { techniczne } \\
\text { w infrastrukturze } \\
\text { hydrotechnicznej }\end{array}$ & $\begin{array}{l}\text { Zagospodarowanie części lądowej w celu zapewnienia miej- } \\
\text { sca do bezpiecznego cumowania wymaga wybudowania } \\
\text { przystani i miejsc cumowniczych. Lokalizacja przystani } \\
\text { planowana jest na początku i końcu trasy czyli w Oświęcimiu } \\
\text { i Krakowie. Istotne, aby na przystani była odpowiednia infra- } \\
\text { struktura i procedury postępowania istotne ze względów } \\
\text { ekologicznych. Pojemniki do segregacji odpadów, zbiorniki } \\
\text { na wodę zęzową i fekalia powinny stanowić podstawowe } \\
\text { wyposażenie każdej nowoczesnej przystani. Dodatkowo } \\
\text { ważne aby istniały procedury i środki neutralizujące ewentu- } \\
\text { alne wycieki oleju czy paliwa. Lokalizacja stanowisk cu- } \\
\text { mowniczych powinna być atrakcyjna dla turystów oraz zlo- } \\
\text { kalizowana w bliskiej odległości od terenów atrakcyjnych } \\
\text { rekreacyjnie. Rozwiązania techniczne polegające na możli- } \\
\text { wości, pobrania wody, odprowadzenia ścieków, podłączenia } \\
\text { się do energii elektrycznej powstałej z baterii słonecznych, } \\
\text { informowaniu o przepełnionych pojemnikach powinny zostać } \\
\text { zaprojektowane i wykonane w ramach samoobsługowych } \\
\text { miejsc postojowych. }\end{array}$ & Spełnia \\
\hline
\end{tabular}


Tabela 3. Aspekt środowiskowy zrównoważonego rozwoju (cd.)

Table 3. The environmental aspect of sustainable development (cd.)

\begin{tabular}{|c|c|c|}
\hline $\begin{array}{l}\text { Infrastruktura } \\
\text { lądowa }\end{array}$ & $\begin{array}{l}\text { Propozycja przebiegu ścieżki rekreacyjnej dla rowerów, } \\
\text { rolkarzy i narciarzy, powinna przebiegać możliwie blisko } \\
\text { drogi wodnej. Budowa ścieżek rowerowych jest okazją do } \\
\text { naprawy, remontu, budowy zabezpieczeń przeciwpowodzio- } \\
\text { wych w postaci wałów oraz na oczyszczenie terenów } \\
\text { w korycie rzeki. Przebieg i budowa trasy powinna chronić } \\
\text { tereny najbardziej wartościowe pod względem środowisko- } \\
\text { wym. Możliwa jest czasowa emisja zanieczyszczeń i wzmo- } \\
\text { żony hałas w trakcie budowy ale w oparciu o prawidłowo } \\
\text { przeprowadzoną procedurę budowlaną oraz kontakt z jed- } \\
\text { nostką odpowiedzialną za ochronę środowiska na danym } \\
\text { obszarze stan środowiska nie powinien ulec pogorszeniu. }\end{array}$ & Obojętne \\
\hline $\begin{array}{l}\text { Infrastruktura } \\
\text { wędkarska }\end{array}$ & $\begin{array}{l}\text { Powstanie miejsc dla wędkarzy zwiększy bezpieczeństwo } \\
\text { wędkujących i osób korzystających z akwenu wodnego. } \\
\text { Powoduje że np. Okręgowy Związek Wędkarski zacznie } \\
\text { identyfikować się z danym miejscem dbając o infrastrukturę, } \\
\text { wspomagając działania sprzyjające zarybianiu czy utrzyma- } \\
\text { niu czystości wody na danym obszarze (rozpatrywany rów- } \\
\text { nież jako aspekt społeczny). }\end{array}$ & Spełnia \\
\hline $\begin{array}{c}\text { Wzrost } \\
\text { świadomości } \\
\text { ekologicznej } \\
\text { społeczeństwa }\end{array}$ & $\begin{array}{l}\text { Zainteresowanie obszarem badawczym i wzmożony ruch } \\
\text { turystyczny może spowodować wzrost zainteresowania } \\
\text { aspektami ekologicznymi i problemami środowiskowymi } \\
\text { regionu, przy odpowiedniej promocji i działalności eduka- } \\
\text { cyjnej w tym zakresie. }\end{array}$ & Spełnia \\
\hline
\end{tabular}

\section{Literatura}

[1] Kobryń A.: Wielokryterialne wspomaganie decyzji w gospodarowaniu przestrzenią, Difin, Warszawa 2014.

[2] Butowski L.: Morska przestrzeń turystyczna, Turyzm 2014, nr 24/1, s. 57-64.

[3] Kistowski M., Trocha A., Tupaj A.: Kontrasty zagospodarowania i ruchu turystycznego na polskim wybrzeżu Bałtyku na przykładzie gmin Władysławowo i Tolknicko), Krajobrazy rekreacyjne - kształtowanie, wykorzystanie, transformacja. Problemy Ekologii Krajobrazu, t. XXVII, s. 179-187.

[4] Ćwik A.: Metoda „trzech pytań” - próba oceny zgodności zagospodarowania przestrzennego z ideą rozwoju zrównoważonego", Czasopismo Inżynierii Lądowej, Środowiska i Architektury, tom XXXI, zeszyt 61 (nr 3///2014), s. 53-61.

[5] Bolt A., Taraszkiewicz A. Wiśniewski R., Miszewska-Urbańska E.: Zagospodarowanie akwenów wodnych zgodnie z zasadami zrównoważonego rozwoju na przykładzie koncepcji otwarcia rekreacyjno-turystycznego drogi wodnej Górnej Wisły, Materiały Konferencyjne INFRAEKO 2016, Rzeszów-Kraków 2016, s. 43-47.

[6] Bujak-Szwaczka B., Kolas P.,: „Rozwój zrównoważony” prezentacja Multimedialna, http://www.popt.2007-2013.gov.pl \{dostęp: 20.04.2016 r.\}. 
[7] Praca zbiorowa, Monografia dróg wodnych śródlądowych w Polsce, Instytut Meteorologii i Gospodarki Wodnej, WKiŁ., Warszawa 1985.

[8] Praca zbiorowa pod redakcją Sądaga T., Informator nawigacyjny śródlądowej drogi wodnej Górnej Wisły, RZGW w Krakowie, Kraków 2012.

[9] Kulczyk J., Winter J. Śródlądowy transport wodny, Oficyna Wydawnicza Politechniki Wrocławskiej, Wrocław 2003.

[10] Bolt A., Bosak W., Miszewska-Urbańska E.: Rekreacyjno turystyczne otwarcie drogi wodnej Oświęcim - Kraków, Materiał na Sympozjum Hydrotechnika 2016 (w recenzji).

[11] Ministerstwo Gospodarki Morskiej i Żeglugi Śródlądowej, http://www.facebook. com/MGMiZS, \{dostęp: 12.04.2016 r.\}.

\section{COMPLIANCE TESTING CONCEPT OPEN RECREATION AND TOURISM WATER ROUTES OF OŚWIECCIM - KRAKOW WITH THE PRINCIPLES OF SUSTAINABLE DEVELOPMENT}

\section{S u m m a r y}

The paper presents a method for assessing the degree of compliance management body of water in accordance with the principles of sustainable development. Research area was the waterway end five key factors were considered, and if the concept is consistent or inconsistent with the prin between Auschwitz and Krakow along with adjacent areas. The research was the concept of tourism and recreational use of inland waterway Upper Vistula. The concept consisted of five elements, ie.: bicycle paths along the river, along with a network of rental, housboatingu, two marinas located at the beginning and end of the route, and self-service berths between Auschwitz and Krakow. Examining the degree of compliance with the principles of the concept of sustainable development we have been considered in three main aspects: economic, social and environmental. Within each of the three aspects identificiples of sustainable development. The work has to undergo analysis of the concept of tourism and recreational development of the Upper Vistula, to draw attention to the problem of proper water management areas in terms of not only local but also global, and places special emphasis on the initial phase of investment planning at the stage of feasibility study particularly in the functioning and operation.

Keywords: water management areas, fishing, marina, mooring post, bike paths, houseboating, the development of roads navigable inland-governmental

DOI:10.7862/rb.2016.165

Przestano do redakcji: $01.05 .2016 r$.

Przyjęto do druku: 28.06.2016 r. 